\title{
Strangulated femoral hernia without intestinal obstruction? Be aware of Meckel's diverticulum: a case report of a Littre's hernia
}

\author{
Dimitrios Kehagias, Evangelos Iliopoulos, loannis Maroulis, Francesk Mulita
}

Department of General Surgery, University General Hospital of Patras Holy Mary the Help, Patras, Greece

\section{Correspondence to} Francesk Mulita; oknarfmulita@hotmail.com

Accepted 1 June 2021

\section{DESCRIPTION}

A 51-year-old woman with a free medical history and no surgical intervention was admitted to our emergency department (ED) reporting for a sudden painful bulging in the right groin accompanied by mild fever $37.5^{\circ} \mathrm{C}$ and nausea. She did not mention any pathology or previous hernia in this area. During physical examination normal bowel sounds were auscultated, there were no signs of abdominal flatulence or tenderness and a painful swelling was palpated in the right groin, just below the inguinal ligament. Although the most likely diagnosis was a strangulated femoral hernia, the absence of clinical signs for intestinal obstruction and an abdominal X-ray without airfluid levels created doubts regarding the correct diagnosis. A CT was performed in order to obtain more information preoperatively. The CT scan showed a blind ending tubular structure, surrounded with fluid in the right femoral canal, closely related to a small intestine loop, raising suspicion for a Littre's hernia (figure 1A,B). In the CT, the neck of the hernia was well recognised and as well the closed affiliation with the femoral vein to the right. The patient underwent emergency surgery and a low groin approach was decided with an oblique incision just above the hernia. The hernia sac was opened and an incarcerated Meckel's diverticulum (MD) with reversible ischaemic lesions was found (figure 2). The hernia ring was incised on its medial aspect and the MD was removed with a stapler. The hernia sac was reduced and a plug mesh was used to close the defect, which was sutured to the inguinal

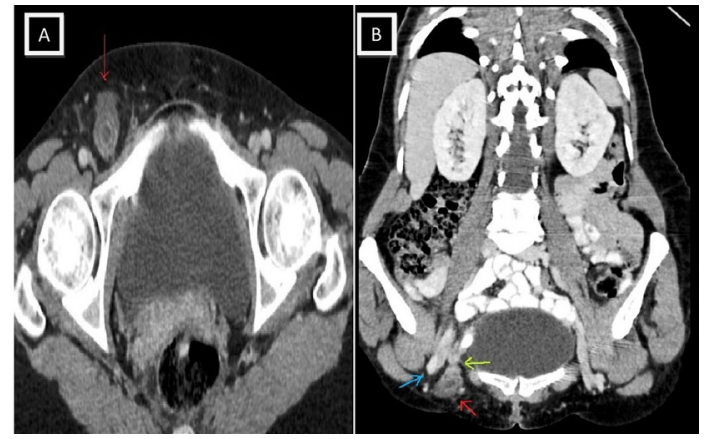

Figure 1 (A) Tubular-shaped structure with thickened wall and fluid, medial to the femoral vessels (red arrow). (B) Tubular-shaped structure in the femoral canal (red arrow), neck of the hernia sac (green arrow) and femoral vein (blue arrow) are shown in the $\mathrm{CT}$ scan.

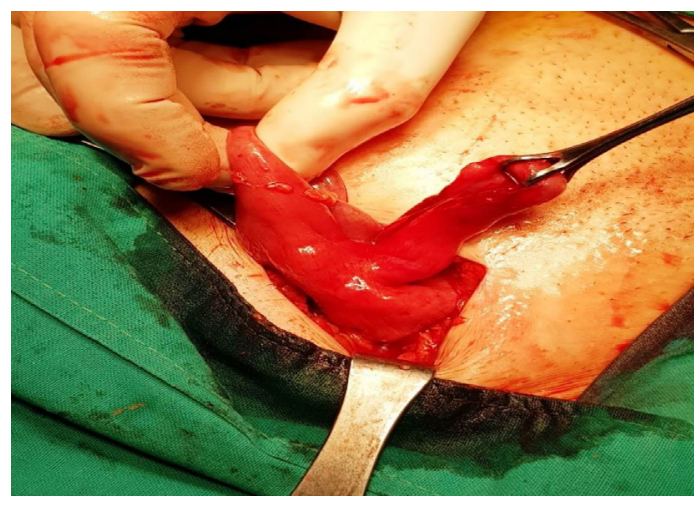

Figure 2 Meckel's diverticulum with ischaemic lesions protruding from the femoral canal.

ligament and into the pectineal fascia. The patient was discharged on the fourth postoperative day without any complications.

MD is a remnant of the omphalomesenteric duct and it occurs in about $2 \%$ of the general population. Only $4 \%$ of patients with MD will require admission to the ED due to complications. The existence of MD inside a hernia sac is even more unusual, with unknown frequency and it is defined as Littre's hernia. ${ }^{1}$ Femoral hernia occurs more often to women and is a quite uncommon diagnosis, accounting only $4 \%-5 \%$ of all hernias. ${ }^{2} \mathrm{~A}$ painful bulging in the groin area is not always a femoral hernia and it has to be distinguished from an inguinal hernia, enlarged lymph nodes, hydrocele, varicose of great saphenous vein or a femoral artery aneurysm. ${ }^{3}$ Another rare cause of bulging in the right groin area is Amyands' hernia, where the appendix is entrapped in the hernia sac inside the inguinal canal. ${ }^{4}$ The symptoms of a femoral hernia depend on the contents of the hernia sac. Usually, it contains a loop of small intestine and it is presented with signs of intestinal obstruction. When the hernia sac contains a hollow viscus, without causing intestinal obstruction other rare diagnosis have to be considered. Richter's hernia, where only a part of the intestinal wall is strangulated, De Garengeot hernia, where the appendix is incarcerated in the femoral canal and Littre's hernia belong to this category of strangulated femoral hernias without intestinal obstruction..$^{5}$ A true Littre hernia, that contains only MD, presents with no signs of intestinal obstruction and the normal function of the gastrointestinal tract is preserved. The rarity of this hernia and the silent clinical signs lead to a difficult preoperative diagnosis and the definite diagnosis of Littre's hernia 
is usually reached intraoperatively. ${ }^{67}$ In our case, the presence of a femoral hernia without signs of intestinal obstruction lead to the CT scan that revealed the above diagnostic sign and Littre's hernia was established as the primary diagnosis. The repair of Littre's hernia includes both MD removal and hernia repair.

Learning points

- Littre's hernia is an extremely rare entity occurring usually in the femoral canal.

- A femoral hernia with no signs of intestinal obstruction should raise suspicions preoperatively for the presence of a Littre's hernia. In such patients conducting a CT scan may have a key role in reaching this difficult diagnosis before surgery.

- The number of patients with Littre's hernia in the literature is scarce and more cases need to be reported in order to achieve the best clinical management.

Contributors DK and El had the idea of the study. FM and DK prepared the manuscript. FM and IM critically revised the manuscript. All authors accepted the final version of the manuscript.
Funding The authors have not declared a specific grant for this research from any funding agency in the public, commercial or not-for-profit sectors.

Competing interests None declared.

Patient consent for publication Obtained.

Provenance and peer review Not commissioned; externally peer reviewed.

ORCID iD

Francesk Mulita http://orcid.org/0000-0001-7198-2628

\section{REFERENCES}

1 Racy M, Ramesh S. Littré meets de Garengeot: Meckel's diverticulum and appendix in a femoral hernia. Ann R Coll Surg Engl 2013;95:e9-10.

2 Hernandez-Richter T, Schardey HM, Rau HG, et al. The femoral hernia: an ideal approach for the transabdominal preperitoneal technique (TAPP). Surg Endosc 2000;14:736-40.

3 Alzaraa A. Unusual contents of the femoral hernia. ISRN Obstet Gynecol 2011:2011:1-2.

4 Michalinos A, Moris D, Vernadakis S. Amyand's hernia: a review. Am J Surg 2014;207:989-95

5 Misiak P, Piskorz L, Kutwin L, et al. Strangulation of a Meckel's diverticulum in a femoral hernia (Littre's hernia). Prz Gastroenterol 2014;9:172-4.

6 Skandalakis PN, Zoras O, Skandalakis JE, et al. Littre hernia: surgical anatomy, embryology, and technique of repair. Am Surg 2006:72:238-43.

7 Muakkassa FF, Abouchedid C. Littre's hernia. N J Med 1987;84:653-5.

Copyright 2021 BMJ Publishing Group. All rights reserved. For permission to reuse any of this content visit

https://www.bmj.com/company/products-services/rights-and-licensing/permissions/

BMJ Case Report Fellows may re-use this article for personal use and teaching without any further permission.

Become a Fellow of BMJ Case Reports today and you can:

- Submit as many cases as you like

- Enjoy fast sympathetic peer review and rapid publication of accepted articles

- Access all the published articles

Re-use any of the published material for personal use and teaching without further permission

\section{Customer Service}

If you have any further queries about your subscription, please contact our customer services team on +44 (0) 2071111105 or via email at support@bmj.com.

Visit casereports.bmj.com for more articles like this and to become a Fellow 